\title{
Performance of Semi-dwarf Apple Rootstocks in Two-dimensional Training Systems
}

\author{
Nicola Dallabetta, Andrea Guerra, and Jonathan Pasqualini \\ Fondazione Edmund Mach-Istituto Agrario di San Michele all'Adige, \\ Technology Transfer Center, San Michele a/A, TN, Italy
}

\section{Gennaro Fazio}

U.S. Department of Agriculture Agricultural Research Service, Plant Genetics Resources Unit, Cornell AgriTech, Geneva, NY 14456; and Horticulture Section, School of Integrative Plant Sciences, Cornell AgriTech, Cornell University, Geneva, NY 14456

Additional index words. fruit size, fruit quality, yield efficiency, planar training system, mechanical pruning, crop value

\begin{abstract}
In 2014, an intensive multileader apple rootstock orchard trial was established in Trento province, Northern Italy, using dwarf ('M.9-T337') and semidwarf rootstocks ('G.935', 'G.969', and 'M.116') and 'Gala', 'Golden Delicious', and 'Fuji' as the scion cultivars. Trees were trained to Biaxis ('M.9-T337') and Triaxis systems ('G.935', 'G.969', and 'M.116') with a tree density of 3175 trees and 2116 trees per hectare, respectively, and with a uniform axis (leader) density of 6348/ha. Comparisons across all training systems by cultivar system showed that after 6 years (2019), trees of 'Fuji' and 'Golden Delicious' on 'M.116' were the largest trees followed by 'G.969', 'G.935', and 'M.9-T337'. With 'Gala', trees on 'G.969' were of similar size as trees on 'M.116' and 'G.935'. Trees of 'Fuji' on 'G.935' produced the highest yield followed by 'G.969', 'M.116', and 'M.9-T337'. For 'Gala', trees on 'M.116' produced similarly as the 'M.9T337', whereas with 'Golden Delicious', 'G.969' and 'G.935' had higher yields than 'M.9-T337'. When comparing production per ground surface area (hectare) 'G935' had higher yield than 'M.9-T337' for all the cultivars in this trial. In addition, yield efficiency of 'Fuji' trees on 'G.935' was similar or even higher than trees on 'M.9-T337'. Rootstock did not affect fruit size with 'Fuji'. For Gala, fruit from 'G.969' were significantly larger than those on 'M.116'. 'Golden Delicious' on 'G.969' produced smaller fruit compared with those on 'G.935'. Fruit from trees on 'M.9-T337' had the lowest percentage of red color with 'Fuji' and the highest with 'Gala'. When yield and quality data were combined to produce marketable yield, rootstock had a dramatic effect on the cumulative gross crop value per hectare based on local farm gate values for each scion cultivar.
\end{abstract}

The implementation of dwarfing apple rootstocks in apple orchards worldwide has resulted in increased production efficiency, reduction in input costs and the production of higher quality apples (Robinson et al., 1991,

Received for publication 1 Oct. 2020. Accepted for publication 4 Dec. 2020.

Published online 8 January 2021.

We thank Depaoli Claudio for micro propagating the rootstocks and Antonio Dal Ri of Griba nursery for providing the tri-axis trees. In addition, we would like to acknowledge the many hours of support provided by technical and farm staff at the experimental station of Maso delle Part, where the trees were planted. The contents of this publication do not necessarily reflect the views or policies of the U.S. Department of Agriculture, nor does mention of trade names, commercial products, or organizations imply endorsement by the U.S. government.

G.F. is the corresponding author. E-mail: gennaro. fazio@usda.gov.

This is an open access article distributed under the CC BY-NC-ND license (https://creativecommons. org/licenses/by-nc-nd/4.0/).
1997; Sansavini et al., 1981). Planar or twodimensional (2D) orchard systems combined with dwarfing rootstocks are new components of the economic evolution of apple orchards that has occurred over past 50 years (Gallardo and Brady, 2015). High-density apple orchards using the dwarf rootstock 'M.9T337' and other 'M.9' clones have become the standard in the Trentino region of northern Italy because of the ability of these rootstocks to deliver an early and high cumulative yield. The Trentino region was among the early adopters (1970s) of dwarfed and high density orchards and, in a sense, set the standard for the rest of the world in replacing older seedling and semidwarf plantings resulting in a worldwide increase in per hectare yield, fruit quality and labor efficiency (Robinson, 2011).

Currently, 'M.9' plantings are already in the third consecutive planting in Trentino and in some areas, the new plantings are showing significant signs of replant disease exemplified by stunted, unproductive trees (Mazzola, 1998; Spath et al., 2015). This phenomenon has been observed mainly in poor soil con- ditions and in smaller orchards (typical of the Trentino region), where growers are forced to plant new trees in the same row (Dallabetta et al., 2018). To compensate for the stunting and loss of productivity per tree caused by replant disease and ensure a quick return on investment, many growers have increased tree density in the past decade with a minimum of a 4000 trees per hectare. This density has been determined to obtain a sustainable yield under replant conditions. An orchard's profitability is influenced by planting costs (comprising in large part the cost of trees, which is a function of tree density), the productivity of the trees (greatly influenced by the rootstock), the operating costs and the value of the scion cultivar (DeMarree et al., 2003). Several long-term studies suggest that there is an optimal tree density for each rootstock-scion combination (Adams et al., 2018; Autio et al., 2017b; Robinson et al., 2007 ) and in general terms, a density of 2500 to 3000 trees per hectare should be suitable to obtain a profitable apple orchard, and plantings with more than 3000 trees/ha represent significant diminishing returns on investment. An alternative way to reduce the number of trees per planting and the investment cost is to introduce new rootstock genotypes with slightly higher vigor, tolerant to replant disease and displaying similar or higher yield efficiency as 'M.9-T337' (Reig et al., 2019b). Rootstocks with slightly higher vigor could be trained in multileader architecture, which, for all practical purposes, would generate the same number of "sun-capturing" stems as individual trees planted at higher density. This concept has evolved over the past 20 years and absolutely requires productive, yieldefficient, precocious rootstocks (Palmer, 2011) as one of the key elements in the orchard puzzle to obtain sustainable economic returns (Autio et al., 2017a). Multileader "bi-axis" trees on 'M.9' rootstock have been planted commercially in Trentino since 2005 in highdensity apple orchards to facilitate technical operations and mechanization (Dorigoni et al., 2011). Orchard canopies featuring planar multileader trees have been proposed as a way to increase light interception and distribution within the canopy, thereby leading to a potential increase in yield (Tustin and van Hooijdonk, 2016; van Hooijdonk et al., 2016).

New dwarfing apple rootstocks, tolerant to biotic and abiotic stressors, with higher vigor than 'M.9-T337', have been under trial at the research Institute of Edmund Mach Foundation and trained to "multileader" systems with the objective of using lower planting densities while managing vigor by dividing it into multiple axes/stems. In this study, we evaluated yield and fruit quality parameters of several semidwarfing rootstock genotypes in an intensive planting featuring a multileader system.

\section{Materials and Methods}

Site description, plant material, and experimental design. In Spring 2014, an orchard trial was established in Maso delle Part in the Trento province of Northern Italy (lat. 
$46^{\circ} 11^{\prime} 18^{\prime \prime} \mathrm{N}$, long. $11^{\circ} 06^{\prime} 11^{\prime \prime} \mathrm{E}$ ), one of the experimental farms of the Edmund Mach Foundation, located at $210 \mathrm{~m}$ a.s.1. in the Adige Valley. Soil was a sandy loam with a $\mathrm{pH}$ of 7.7.

Scion varieties 'Buckeye ${ }^{\circledR}$ Gala Simmons', 'Fuji Kiku ${ }^{\circledR}$ Fubrax', and 'Golden Delicious clone B' were grafted in Aug. 2012 on four rootstock genotypes: two Malling series ('M.9-T337' and 'M.116') and two Geneva series ['Geneva ${ }^{\circledR} 935$ (G.935)' and 'Geneva ${ }^{\circledR} 969$ (G.969)']. The Geneva ${ }^{\circledR}$ rootstocks were propagated by micropropagation, whereas the Malling stock series were propagated by conventional stool bed methods. The rootstocks 'M.116', 'G.935', and 'G.969' were chip budded in Aug. 2012 using three or four dormant buds, and three leaders were selected during the following year to form a triaxis tree. M9-T337 was budded in the same year by a different nursery with two dormant buds using the chip-budding technique to form a biaxis tree $\left(\right.$ Bibaum $\left.^{\circledR}\right)$.

Feathered trees were delivered and planted in Spring 2014 and spaced $1.00 \mathrm{~m}$ (biaxis) and $1.50 \mathrm{~m}$ (triaxis) $\times 3.15 \mathrm{~m}$, with a tree density of $3175 /$ ha and $2116 /$ ha, respectively (Fig. 1).

The experiment was arranged in separate but contiguous orchard blocks for each cultivar, and within each cultivar, each planting was arranged as a randomized complete block with three replications. For each cultivar experiment four rootstocks were the treatment and within each replicate, experimental units consisted of four-tree units surrounded by two guard trees (nondata) to minimize edge effects caused by light competition. Each tree had all the axes (leaders) trained at a distance of 50 $\mathrm{cm}$ from each other and trees were oriented toward a North-South direction (Fig. 1).

Tree management. Trees were developed by heading back the weaker leaders and leaving the stronger ones unheaded at planting until they reached 3.3 to $3.5 \mathrm{~m}$ height.

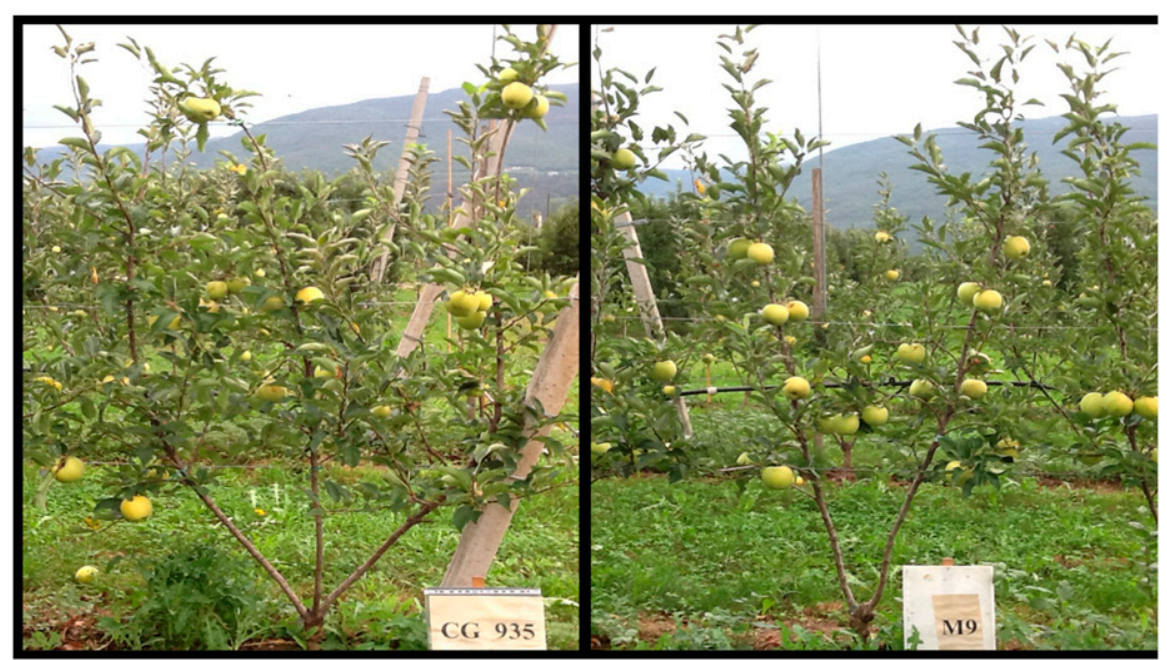

Fig. 1. Example of biaxis ('M.9-T337' right panel) and triaxis ('G.935' left panel) trees cropped in 2015 (second leaf). Planting located at the Edmund Mach Foundation experimental station of Maso delle Part, Trentino, Italy.

Competitor shoots of the leaders were removed annually. Lateral branches, larger than half of the trunk diameter of the leaders and/or limbs with a narrow crotch angle were removed back to the trunk with an angled cut to develop flatter replacement limbs. Each year, one or two lateral branches in the biaxis and two or three lateral branches in the triaxis trees were removed. Lateral branches were kept simple by removing sublaterals to create a single axis for each branch and shortened to 50 to $60 \mathrm{~cm}$ by cutting to a sublateral. Tree height was limited to $3.3 \mathrm{~m}$ by heading back the leader or cutting the leader to a lateral weak branch each year. Beginning in year 4 , trees were mechanically pruned in summer (hedging and topping) when shoot growth had 12 to 13 new leaves. All trees were manually pruned during wintertime and managed according to commercial practices for integrated crop and pest management. Chemical thinning strategies differed according to cultivar and years and included applications of ammonium thiosulfate (ATS), benzyladenine, naphthalene acetic acid (NAA), naphthalene acetamide (NAD), and ethephon followed by manual thinning (Supplemental Table 1). Trees were supported by a four-wire trellis $(3.0 \mathrm{~m}$ tall $)$ with wires spaced $50 \mathrm{~cm}$ apart and cement support poles.

Horticultural assessment. Trees were evaluated for 6 years, from planting (2014) until 2019. From the second year (2015) onward, fruits were harvested and graded using a Greefa color and size grading machine (Tricht, Netherlands) and assessed for weight (grams), size (millimeters), and color ( $\%$ red). Trunk circumference was measured each year at the end of the season $10 \mathrm{~cm}$ above the point where the axes (main leaders) were developed and used to calculate trunk cross-sectional area (TCSA $-\mathrm{cm}^{2}$ ). Whole tree TCSAs were obtained as a sum of all the axes TCSAs; we used the final TCSA measurement for all calculations. In 2017 (fourth leaf) data were collected for tree canopy

HortScience Vol. 56(2) February 2021 volume by measuring tree height $(70 \mathrm{~cm}$ above graft union), tree depth and tree width and expressed in cubic meters. Cumulative yield (CY) per tree was calculated by adding the yields obtained in the 2015-19 seasons. Cumulative yield per ground surface area (tons/hectare) was calculated by multiplying tree yield by the number of trees per hectare at the density trees were planted [biaxis 'M.9$\mathrm{T} 337^{\prime}-1.00 \times 3.15 \mathrm{~m}=3175$ trees/ha; triaxis ('G.935', 'G.969', 'M.116') - $1.50 \times 3.15=$ 2116 trees/ha]. CY efficiency (CYE) was calculated as the cumulative yield $(\mathrm{kg} /$ tree) of 5 years (2015-19) divided by the last TCSA (2019). Average fruit number (AFN), weight (AFW) (grams), and color (\%) refers to the average over 5 years $(2015-19)$. Economic returns per hectare for each cultivar were based on local average farm gate sale values for years 2015-18 adjusted for size and color category for each rootstock.

Statistical analysis. The statistical analyses were carried out using SAS JMP Pro 14 software (SAS Institute Inc., Cary, NC). Separate analysis of variance (linear mixed models) was used for each cultivar to determine the effects of rootstocks on the variables of interest. The model was set up with rootstock as a fixed effect and block as a random effect. To control the number of false positives Tukey's honestly significant difference method was used to generate pairwise comparisons, at $\alpha=0.05$. The relationship between AFN and AFW and between AFN and $\%$ red color was explored by performing a series of linear regressions between the variables for each rootstock within each cultivar experiment.

\section{Results and Discussion}

Tree size. Rootstock genotype significantly affected tree size as estimated using TCSA (Tables 1 and 2). 'Golden', 'Gala', and 'Fuji' trees on 'M.116' produced the largest trees, followed by trees on 'G.969', 'G.935', and 'M.9-T337'. The size of a compound apple tree is influenced by the rootstock's inherent genetics and the interactions with scion, soil, water, nutrients, canopy management, diseases, and insects (Fazio et al., 2014). Although the scion effects could not be estimated in this experiment because they were planted in different but contiguous orchard plots, the vigor of the varieties agreed with the general known trends that describe 'Fuji' trees being more vigorous than 'Golden' and 'Gala'. In these experiments 'G.935' was statistically smaller than 'G.969' with scion varieties 'Fuji' and 'Golden'. A previous field trial in Geneva, NY, featuring 'Golden Delicious' scion did not show a statistical difference between tree sizes on 'G.935' and 'G.969' (Russo et al., 2007). However, it did confirm results that showed 'G.935' and 'G.969' produce larger tree size than 'M.9' with 'Golden Delicious', 'Honeycrisp', and 'Fuji' cultivars (Robinson et al., 2014). Although 'Gala' trees grafted on 'G.969' were not significantly different in tree size than trees on 'M.116' and 'G.935' (Table 3), they 
Table 1. Least square means estimates and SE for yield component variables of adjacent rootstock trials planted in the Trentino, Italy, region in 2014 featuring three scion varieties and four rootstocks after 5 years of evaluation.

\begin{tabular}{|c|c|c|c|c|c|c|c|c|c|c|c|}
\hline \multirow[b]{2}{*}{ Scion } & \multirow[b]{2}{*}{ Rootstock } & \multicolumn{2}{|c|}{$\operatorname{TCSA}\left(\mathrm{cm}^{2}\right)$} & \multicolumn{2}{|c|}{ Yield/tree $(\mathrm{kg})$} & \multicolumn{2}{|c|}{$\mathrm{AFN}$} & \multicolumn{2}{|c|}{ CYE $\left(\mathrm{kg} / \mathrm{cm}^{2}\right)$} & \multicolumn{2}{|c|}{ Tons/ha } \\
\hline & & Estimate & SE & Estimate & SE & Estimate & SE & Estimate & SE & Estimate & SE \\
\hline \multirow[t]{4}{*}{ Fuji } & G.935 & 31.06 & 4.85 & 127.73 & 8.37 & 105.00 & 6.17 & 4.30 & 0.17 & 270.73 & 20.32 \\
\hline & G.969 & 39.24 & 4.81 & 109.31 & 8.30 & 88.48 & 6.12 & 2.80 & 0.16 & 231.30 & 20.15 \\
\hline & M.116 & 51.53 & 4.81 & 70.75 & 8.30 & 58.55 & 6.12 & 1.41 & 0.16 & 149.72 & 20.15 \\
\hline & M.9-T337 & 18.49 & 4.85 & 54.17 & 8.37 & 44.36 & 6.17 & 2.92 & 0.17 & 171.84 & 20.32 \\
\hline \multirow[t]{4}{*}{ Gala } & G.935 & 28.81 & 4.41 & 123.54 & 10.13 & 144.38 & 11.46 & 4.53 & 0.31 & 261.41 & 22.03 \\
\hline & G.969 & 33.11 & 4.41 & 99.02 & 10.13 & 112.86 & 11.46 & 3.00 & 0.31 & 209.54 & 22.03 \\
\hline & M.116 & 39.79 & 4.41 & 77.94 & 10.13 & 88.9 & 11.46 & 2.02 & 0.31 & 164.92 & 22.03 \\
\hline & M.9-T337 & 14.13 & 4.46 & 63.37 & 10.25 & 73.48 & 11.61 & 4.66 & 0.31 & 200.01 & 22.28 \\
\hline \multirow[t]{4}{*}{ Golden } & G.935 & 26.86 & 2.16 & 127.37 & 7.01 & 108.66 & 6.94 & 4.77 & 0.20 & 269.53 & 14.79 \\
\hline & G.969 & 31.76 & 2.16 & 122.72 & 7.01 & 109.45 & 6.94 & 3.89 & 0.20 & 259.69 & 14.79 \\
\hline & M.116 & 45.59 & 2.19 & 113.25 & 7.12 & 93.73 & 7.03 & 2.50 & 0.20 & 239.47 & 15.05 \\
\hline & M.9-T337 & 13.89 & 2.16 & 72.98 & 7.01 & 63.46 & 6.94 & 5.35 & 0.20 & 231.71 & 14.79 \\
\hline
\end{tabular}

$\mathrm{TCSA}=$ trunk cross sectional area; $\mathrm{AFN}=$ average fruit number per tree; $\mathrm{CYE}=$ cumulative yield efficiency.

did rank similarly to the 'Fuji' and 'Golden' in this planting. This lack of clear mean separation in 'Gala' may have occurred because of this scion's inherent growth and flowering properties (weaker and with no biennial tendencies), which may partition carbohydrates further toward fruit production instead of vegetative growth. Similar observations are relevant with 'Honeycrisp' grown on 'G.969' and 'G.935' (Robinson et al., 2011a). Data collected on tree canopy volume (Fig. 2) showed as expected that trees with three axis (leaders) were larger than trees on 'M.9-T337' which had only two leaders. However, when that value was adjusted by dividing by the number of leaders (upper panel Fig. 2), it showed that canopy volume values were very similar for 'Fuji', perhaps with 'G.935' showing lesser vegetative growth overall. Adjusted canopy volume for 'Gala' and 'Golden' was consistently higher for 'G.969' and 'M.116' compared with 'G.935' and 'M.9'. Canopy volume is largely influenced by rootstock (bearing and dwarfing capacities) but is also affected by planting density where the same rootstockscion combination planted at higher density will be smaller than when planted at lower density, likely due to light and root compe- tition (Reig et al., 2020). However, when considering leader volume, 'G.935' was more similar to 'M.9-T337'.

Yield. Cumulative yield per tree differed significantly in all pairwise comparisons in the 'Fuji' and 'Gala' experiments (Table 2) except for the 'M.9-T337' contrast with 'M.116' with 'Gala'. However, this was not the case in the 'Golden' experiment where $\mathrm{CY} /$ tree was significantly different in pairwise comparisons between 'M.9-T337' and the other rootstocks where 'M.9-T337' always had the lowest yields. In contrast, trees on 'G.935' had the highest CY/tree for all the cultivars and significantly higher than trees on 'M.9-T337', which corroborate results observed in trials in the United States, including NC-140 multisite trial featuring 'Gala', 'Honeycrisp', 'Fuji', and 'Golden Delicious' (Autio et al., 2011; ChavezGonzalez et al., 2011; Marini et al., 2009, 2014; Reig et al., 2018, 2019a; Wallis et al., 2017).

Rootstock genotype had a significant effect on average fruit number per tree (AFN) (Tables 1 and 2). With 'Fuji', trees on 'G.935' produced the highest AFN, followed by trees on 'G.969', 'M.116', and 'M.9T337'. This trend was similar in the 'Gala' and 'Golden' experiments, with 'G.935' being very similar to 'G.969' in 'Golden' and 'M.116' being similar to 'M.9-T337' in 'Gala'. The average fruit number per tree (per year) reflects management choices such as thinning (performed uniformly in all plots) and the ability of the rootstock to provide enough nutrition to the canopy to support flower and fruit development (Chun et al., 2002; Fazio et al., 2020; Wunsche and Ferguson, 2005). Furthermore, AFN is affected by the rootstock ability to partition carbon resources toward fruit production instead of vegetative growth (influenced by precocity and/or increase in flower density per branch cross sectional area) (Stutte et al., 1994), axillary bud development and canopy renewal (absence of blind wood) (Fazio and Robinson, 2008b; van Hooijdonk et al., 2011), and influence on return bloom (low biennial bearing) (Reig et al., 2019b). All these may explain why AFN per tree range was low in 'Gala' and 'Golden' for 'M.9-T.337' (Fig. 3). 'G.935' is well known to confer high precocity like M.9-T337 (Reig et al., 2019a) and in the nursery has shown higher potential for sylleptic branching than 'M.9' clones (Fazio and Robinson, 2008a).

Table 2. Pairwise least square means comparisons using Tukey's honestly significant difference and comparison sE for yield component variables of adjacent rootstock trials planted in the Trentino, Italy region in 2014 featuring three scion varieties and four rootstocks after five years of evaluation.

\begin{tabular}{|c|c|c|c|c|c|c|c|c|c|c|c|c|c|c|c|c|c|}
\hline \multirow[b]{2}{*}{ Scion } & \multicolumn{2}{|c|}{ Comparison } & \multicolumn{3}{|c|}{ TCSA } & \multicolumn{3}{|c|}{ Yield/tree } & \multicolumn{3}{|c|}{ AFN } & \multicolumn{3}{|c|}{ CYE } & \multicolumn{3}{|c|}{ Tons/ha } \\
\hline & Rootstock & -Rootstock & Diff. & SE & Prob $>|t|$ & Diff. & SE & Prob $>|t|$ & Diff. & $\mathrm{SE}$ & $\overline{\operatorname{Prob}>|t|}$ & Diff. & $\mathrm{SE}$ & $\overline{\text { Prob }>|t|}$ & Diff. & SE & $\overline{\text { Prob }>|t|}$ \\
\hline & & M.116 & -20.47 & 2.82 & $<0.0001$ & .98 & 4.94 & $<0.0001$ & 6.46 & 88 & $<0.0001$ & 2.89 & 0.26 & $<0.0001$ & 121.01 & 12.13 & 0.0001 \\
\hline & & M.9-T & 12.57 & 2.88 & 0.0005 & 73.57 & 5.05 & $<0.0001$ & 0.65 & 3.97 & $<0.0001$ & 1.38 & 0.27 & $<0.0001$ & 98.90 & 12.41 & $<0.0001$ \\
\hline & G.969 & M.9-T337 & 20.74 & 2.82 & $<0.0001$ & 55.14 & 4.94 & $<0.0001$ & 4.12 & 3.88 & $<0.0001$ & -0.12 & 0.26 & & 59.46 & 12.13 & $<0.0001$ \\
\hline & & & .04 & 2.82 & $<0.0$ & & 4.94 & & & & & -1.51 & 0.26 & $<0$. & -22.12 & 12. & 0.2774 \\
\hline \multirow[t]{4}{*}{ Gala } & & & -4.30 & 3.11 & & .51 & 7.07 & & 1.52 & 8.55 & & 1.53 & 0.27 & $<0.0$ & 87 & 15. & 0.0083 \\
\hline & 969 & $\mathrm{~N}$ & -6.68 & 3.11 & 0.1555 & 1.09 & 7.07 & & 3.97 & 8.55 & & 0.98 & 0.27 & & 44.62 & 15. & 0.0286 \\
\hline & 969 & & 18.98 & 3.18 & $<0.0001$ & & 7.24 & $<0.00$ & & & & -1.66 & 0.28 & $<0.0001$ & 9.54 & 70 & 0.9292 \\
\hline & & & & 3. & & & 7.24 & & & & & -2.64 & 0.28 & & -35.09 & & \\
\hline \multirow[t]{4}{*}{ Golden } & 935 & & -4.91 & 1.51 & 0.01 & 4.65 & 5.67 & 0.8443 & -0.78 & 5.04 & 0.9986 & 0.89 & 0.26 & & 9.84 & 12.86 & 0.8695 \\
\hline & 935 & & -18.73 & 1.54 & $<0.00$ & 4.13 & 5.80 & & 14.93 & 5.16 & 0.0 & 2.27 & 0.26 & $<0.0001$ & 30.06 & 13.16 & 0.1185 \\
\hline & .935 & .9-T337 & 12.97 & 1.51 & $<0.0001$ & 54.39 & 5.67 & $<0.0001$ & 45.20 & 5.04 & $<0.0001$ & -0.57 & 0.26 & & 37.82 & 12.86 & 0.0264 \\
\hline & G.969 & 1.116 & -13.82 & 1.54 & $<0.0001$ & 9.48 & 5.80 & 0.3714 & 15.71 & 5.16 & 0.0203 & 1.38 & 0.26 & $<0.0001$ & 20.22 & 13.16 & 0.4257 \\
\hline
\end{tabular}

$\mathrm{TCSA}=$ trunk cross sectional area; $\mathrm{AFN}=$ average fruit number per tree; CYE $=$ cumulative yield efficiency. 
Table 3. Least square means estimates and SE for fruit quality variables of adjacent rootstock trials planted in the Trentino, Italy, region in 2014 featuring three scion varieties and four rootstocks after 5 years of evaluation.

\begin{tabular}{|c|c|c|c|c|c|c|c|c|c|c|c|}
\hline \multirow[b]{2}{*}{ Scion } & \multirow[b]{2}{*}{ Rootstock } & \multicolumn{2}{|c|}{$\mathrm{AFW}$} & \multicolumn{2}{|c|}{$\%<70 \mathrm{~mm}$} & \multicolumn{2}{|c|}{$\% 70-80 \mathrm{~mm}$} & \multicolumn{2}{|c|}{$\%>80 \mathrm{~mm}$} & \multicolumn{2}{|c|}{$\%$ Red color } \\
\hline & & Estimate & SE & Estimate & SE & Estimate & $\mathrm{SE}$ & Estimate & SE & Estimate & SE \\
\hline \multirow[t]{4}{*}{ Fuji } & G.935 & 242.82 & 6.67 & 1.89 & 0.52 & 18.87 & 2.87 & 79.24 & 3.20 & 59.04 & $\overline{3.09}$ \\
\hline & G.969 & 245.82 & 6.61 & 1.79 & 0.51 & 18.36 & 2.81 & 79.83 & 3.14 & 64.50 & 3.05 \\
\hline & M.116 & 236.32 & 6.61 & 2.94 & 0.51 & 23.25 & 2.81 & 73.80 & 3.14 & 65.10 & 3.05 \\
\hline & M.9-T337 & 240.15 & 6.67 & 2.37 & 0.52 & 21.42 & 2.87 & 76.20 & 3.20 & 73.12 & 3.09 \\
\hline \multirow[t]{4}{*}{ Gala } & G.935 & 173.95 & 1.90 & 17.54 & 1.67 & 68.37 & 2.20 & 14.07 & 1.79 & 90.54 & 0.97 \\
\hline & G.969 & 180.59 & 1.90 & 11.93 & 1.67 & 67.15 & 2.20 & 20.91 & 1.79 & 90.64 & 0.97 \\
\hline & M.116 & 173.02 & 1.90 & 19.73 & 1.67 & 63.90 & 2.20 & 16.36 & 1.79 & 93.34 & 0.97 \\
\hline & M.9-Т337 & 175.98 & 1.98 & 14.91 & 1.73 & 67.96 & 2.26 & 17.15 & 1.87 & 83.51 & 1.02 \\
\hline \multirow[t]{4}{*}{ Golden } & G.935 & 232.50 & 2.92 & 3.32 & 0.78 & 14.09 & 1.26 & 82.57 & 1.73 & & \\
\hline & G.969 & 220.47 & 2.92 & 3.77 & 0.78 & 19.00 & 1.26 & 77.21 & 1.73 & & \\
\hline & M.116 & 236.29 & 3.02 & 1.03 & 0.81 & 13.08 & 1.32 & 85.88 & 1.79 & & \\
\hline & M.9-Т337 & 229.72 & 2.92 & 2.77 & 0.78 & 19.32 & 1.26 & 77.89 & 1.73 & & \\
\hline
\end{tabular}

$\mathrm{AFW}=$ average fruit weight per tree; $\%<70 \mathrm{~mm}=$ percent of fruit under $70 \mathrm{~mm}$ in diameter; $\% 70-80 \mathrm{~mm}=$ percent of fruit between $70-80 \mathrm{~mm}$ in diameter; $\%>80 \mathrm{~mm}=$ percent of fruit $>70 \mathrm{~mm}$ in diameter

Yield efficiency. CYE is a measure productivity (kilograms of fruit) standardized by tree size (TCSA). In all plantings, CYE was significantly affected by rootstock. With 'Fuji', trees on 'G.935' had the highest CYE, followed by trees on 'M.9-T337' and 'G.969' with trees on 'M.116' displaying the lowest value (Tables 1 and 2). These results agree with previous field trials in the United States that found 'G.935' and 'G.969' to be among the most efficient apple rootstocks tested despite their large size compared with 'M.9' clones (Reig et al., 2018; Robinson et al., 2011b, 2014). The 'Gala' and 'Golden' plantings showed similar CYE values with 'G.935' and 'M.9-T337', with 'M.116' always being the least efficient. These results confirm results from other trials where apple rootstock ' $\mathrm{G} .935$ ' has been consistently identified as one of the most efficient rootstocks in several on-farm trials and in the NC-140 multistate rootstock trials with cultivars including 'Red Delicious', 'Golden Delicious', 'Gala', 'Honeycrisp', and 'Fuji' (Autio et al., 2005; Marini et al., 2009, 2014; Reig et al., 2018, 2019a, 2020; Wallis et al., 2017).

CY per hectare. Production of apples per unit area of land is a useful estimate to gauge the potential economic returns for a given set of production combinations (scion, rootstock, training system). The biggest significant differences in cumulative tons/hectare were observed in the 'Fuji' experiment where 'G.935' displayed the highest yield followed by 'G.969', 'M.9-T337', and lastly 'M.116' (Tables 1 and 2). The 'Gala' planting also showed 'G.935' as the highest yielder and 'M.116' as the lowest yielder with 'M.9T337' and ' $G .969$ ' in the middle with similar yields. The 'Golden' planting instead showed only statistically significant mean separation between 'G.935' and 'M.9-T337' for cumulative tons/hectare. When we designed the experiment, we adjusted tree spacing to give the same number of leaders (axes) per hectare (50 $\mathrm{cm}$ apart within a row) to make uniform the light interception potential of each system based on principles described in the literature (Green et al., 2001; Palmer, 2011; Robinson et al., 1991; Wunsche and Lakso, 2000). The lack of significant differences among rootstock genotypes with 'Golden' and 'Gala' maybe be due to this initial adjustment and the less vigorous growth habit of these two

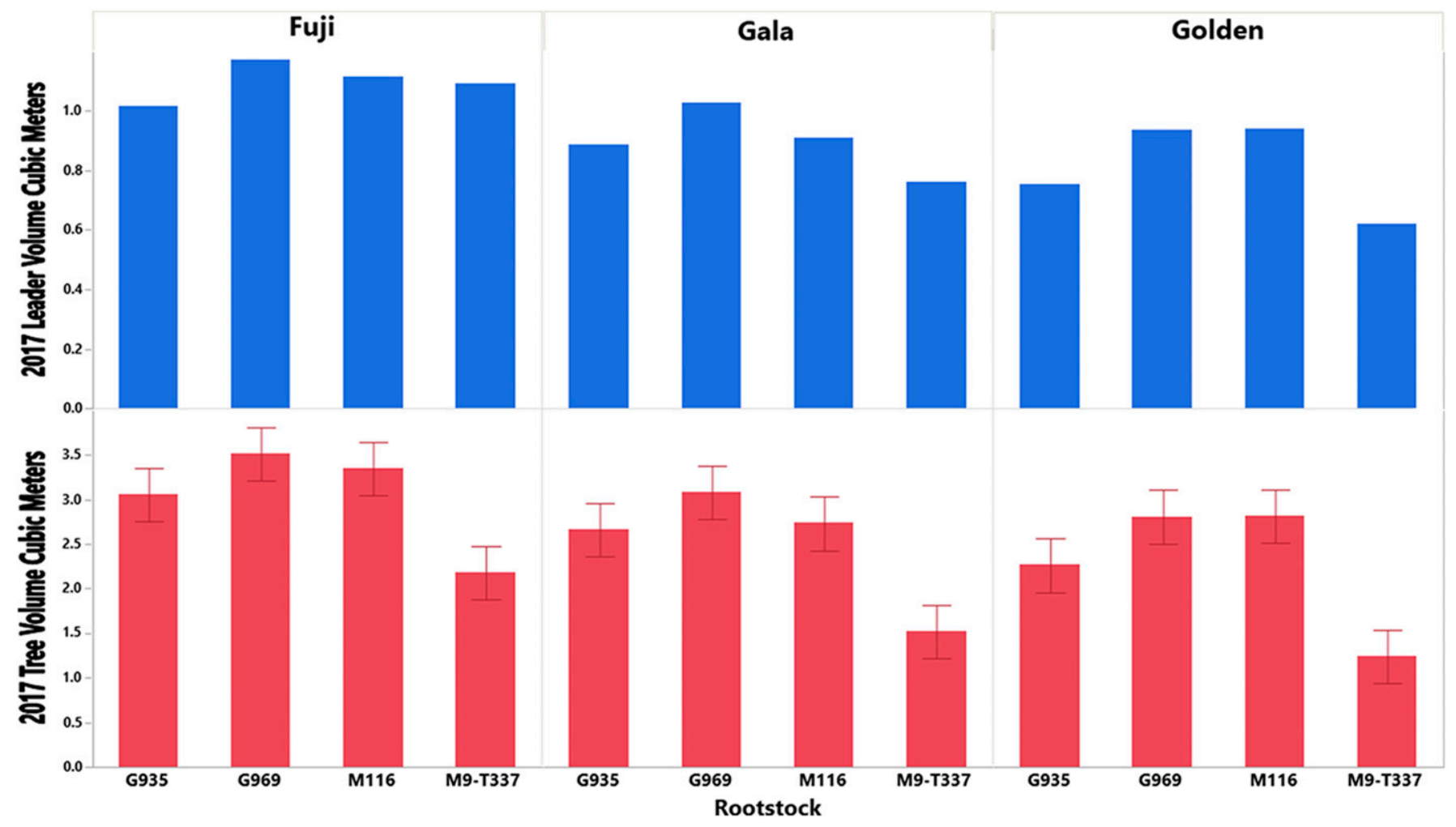

Fig. 2. Mean tree volume (cubic meters) estimates for 2017 and volume estimates adjusted by number of leaders for each tree (mean/2 for biaxis trees and mean/3 for triaxis trees). Planting located at the Edmund Mach Foundation experimental station of Maso delle Part, Trentino, Italy. 


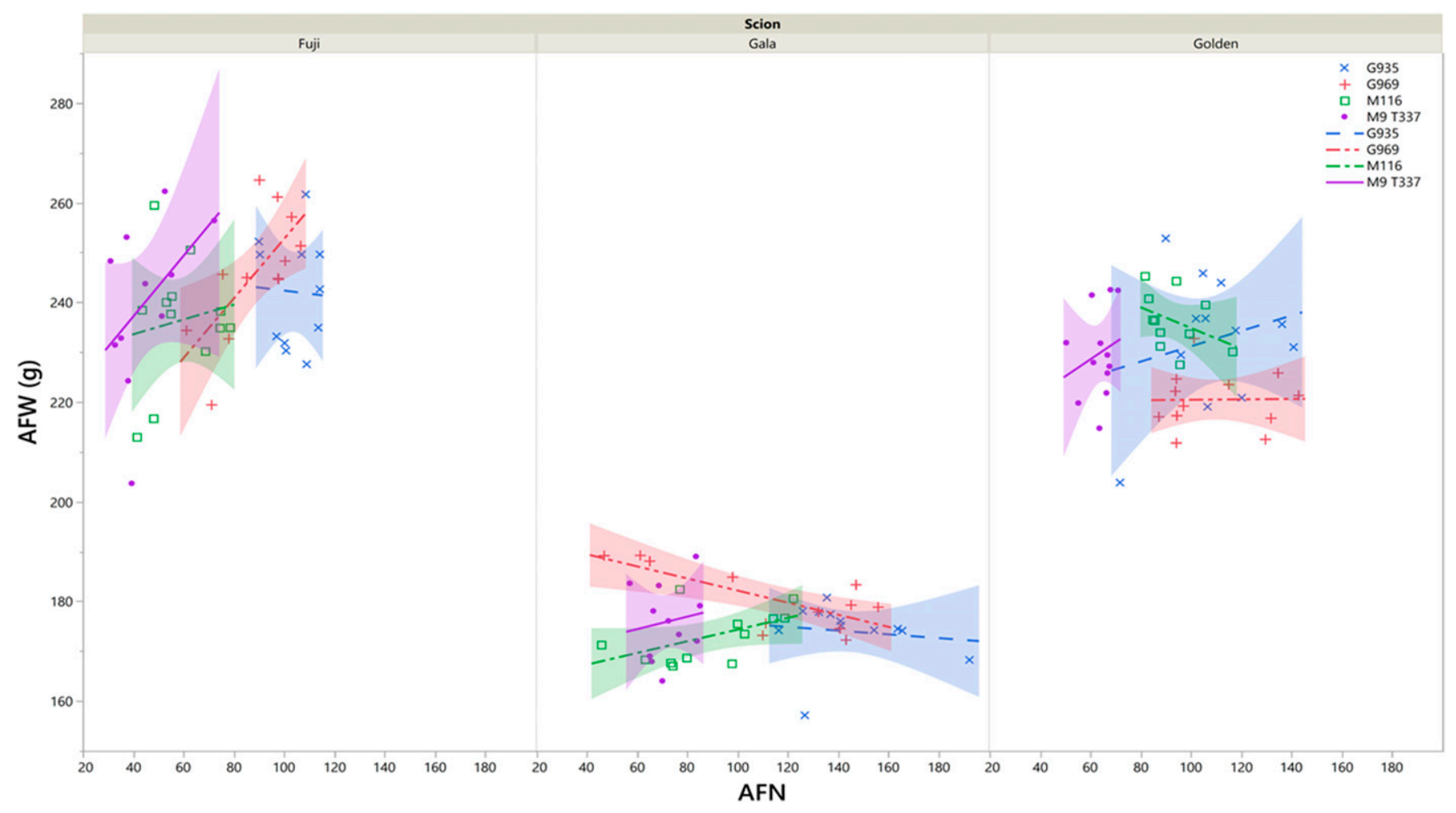

Fig. 3. Separate linear regression figures for each of the tree experiments ('Fuji', 'Gala', and 'Golden') by rootstock. Shaded areas represent $95 \%$ confidence intervals for the regression. Planting located at the Edmund Mach Foundation experimental station of Maso delle Part, Trentino, Italy.

cultivars compared with 'Fuji'. It needs to be noted that 'G.935', 'G.969', and 'M.116' displayed different tree size potential in all three varieties tested and yet were planted at the same density of 2116 trees/ha. It is likely that if the densities were adjusted slightly to reflect measured tree size potential the rootstocks would display more discernable differences in their production potential per land unit area for those varieties. It is also possible that ' $G .935$ ' trained with only two leaders and planted at a higher density could have significantly increased its per hectare production potential. Although this report displays only the early life of an orchard (2015-19), similar longer term research has shown that in high-density systems, the early production trends (first 5 years) are influenced by the precocity potential of the rootstock, the ability to quickly fill the two- or three-dimensional "space" allotted for each tree to capture light energy and the capacity of the rootstock to partition that energy into fruit production (Reig et al., 2018, 2019a, 2019b, 2020). These early trends often dictate the long-term productivity potential of a rootstock-scion-system combination.

Fruit quality. Two of the most important fruit quality parameters valued by marketers and common to most apple cultivars are fruit size and red color (cultivar dependent). Other parameters used in industry but not measured in these experiments are firmness, soluble solids, acidity, and external and internal disorders. Rootstocks have been shown to influence all of these fruit quality parameters (Fallahi et al., 2018; Fazio et al., 2018) as they are an important conduit for nutrition, hormone signaling, tree architecture, and water relations (Adams et al., 2018; Lordan et al., 2017).

No differences were found in AFW between the rootstock genotypes in 'Fuji' cultivar (Tables 3 and 4). This is probably because 'Fuji' normally produces large fruit and trees were thinned to less than the critical crop-load that would have teased out a potential rootstock effect as evidenced by the lack of significant regression effects of AFW to AFN (Fig. 3). Significant rootstock effects on 'Fuji' fruit size have been detected in several long-term experiments (Autio et al., 2011; Reig et al., 2019b), perhaps indicating that the trees in this experiment were thinned to maximize overall size and avoid biennial bearing tendencies of this cultivar thus not reaching the limiting competition among fruit that causes size to drop at higher crop loads.

In the 'Gala' experiment, fruits from 'G.969' were significantly larger than those on 'M.116' (Tables 3 and 4). In addition, trees on 'G.969' produced a higher percentage of fruits over $80 \mathrm{~mm}$ diameter compared with trees on 'G.935' due to the higher AFN produced by trees on 'G.935'. Fruit from Geneva $^{\circledR}$ rootstocks and 'M.9-T337' had similar AFW, despite producing a significantly higher AFN and CY. The smaller variation in AFN for 'M.9-T337' reflects the overall growth potential of 'Gala' on that rootstock and likely due to the number fruiting buds available to set fruit. Comparing the Geneva $^{\circledR}$ rootstocks, 'G.935' was able to produce similar size fruit than 'G.969' even though it produced a significant higher AFN and CY (Tables 3 and 4). Interestingly in this experiment the regression of AFW on AFN showed a significant negative trend for ' $G .969$ ' rootstock (Fig. 3) observed in most 'Gala' crop load experiments (Robinson et al., 2016; Rufato et al., 2017; Yildirim et al., 2016).

In the 'Golden' experiment, trees on 'G.969' produced smaller fruit size compared with those on 'G.935' despite a similar AFN and CY. This was confirmed by the size class distribution where trees on 'G.969' had the lowest percentage of fruit in the largest size class compared with fruit from 'M.116' (Tables 3 and 4). Fruit from 'M.116' and 'M.9-T337' produced larger fruit because crop load was lower than the Geneva ${ }^{\circledR}$ trees (Table 4). Comparing the two Malling rootstocks, 'M.116' had a higher percentage in the largest fruit size class due to the lower CYE. Even though trees on 'G.935' and 'M.9-T337' had similar AFW, the fruit size distribution in the different classes was different (Tables 3 and 4). Trees on 'M.9-T337' had a significantly higher percentage of fruit in the middle class ( $70-80 \mathrm{~mm}$ diameter) and lower in the upper class $(>80 \mathrm{~mm})$ despite being not statistically different compared with trees on 'G.935'. Regression of AFW on AFN in the 'Golden' experiment was not significant (Fig. 3) perhaps for the same reasons indicated for the 'Fuji' experiment. The smaller variation in AFN for 'M.9-T337' reflects the overall growth potential of 'Golden' on that rootstock and likely due to the number fruiting buds available to set fruit. 
Table 4. Pairwise least square means comparisons using Tukey's honestly significant difference and comparison sE for fruit quality variables of adjacent rootstock trials planted in the Trentino, Italy, region in 2014 featuring three scion varieties and four rootstocks after 5 years of evaluation.

\begin{tabular}{|c|c|c|c|c|c|c|c|c|c|c|c|c|c|c|c|c|c|}
\hline \multirow[b]{2}{*}{ Scion } & \multicolumn{2}{|c|}{ Comparison } & \multicolumn{3}{|c|}{ AFW } & \multicolumn{3}{|c|}{$\%<70 \mathrm{~mm}$} & \multicolumn{3}{|c|}{$\% 70-80 \mathrm{~mm}$} & \multicolumn{3}{|c|}{$\%>80 \mathrm{~mm}$} & \multicolumn{3}{|c|}{$\%$ Red color } \\
\hline & Rootstock & -Rootstock & Diff. & $\mathrm{SE}$ & Prob $>|t|$ & Diff. & $\mathrm{SE}$ & $\overline{\text { Prob }>|t|}$ & Diff. & $\mathrm{SE}$ & Prob $>|t|$ & Diff. & $\mathrm{SE}$ & $\overline{\text { Prob }>|t|}$ & Diff. & $\mathrm{SE}$ & Prob $>|t|$ \\
\hline \multirow{3}{*}{$\overline{\text { Fuji }}$} & G.935 & M.116 & 6.505 & 4.173 & 0.4132 & -1.044 & 0.614 & 0.3365 & -4.379 & 2.7462 & 0.3931 & 5.433 & 2.955 & 0.2708 & -6.052 & 2.457 & 0.0815 \\
\hline & & & 670 & 4.173 & & -0.581 & 0.614 & & -3.061 & 2.7462 & & 3.633 & 2.955 & & -8.620 & 2.457 & 0.006 \\
\hline & 116 & & -3.833 & 4.173 & & 0.563 & 0.614 & & 1.825 & 2.7462 & & -2.397 & 2.955 & & -8.020 & 2.457 & 0.0116 \\
\hline \multirow[t]{4}{*}{ Gala } & G.935 & G.969 & -6.638 & 2.566 & 0.0616 & 5.616 & 2.084 & 0.0 & 1.216 & 2.4617 & 0.96 & -6.832 & 2.395 & 328 & -0.101 & 1.570 & 0.9999 \\
\hline & & & 573 & 2.566 & & -7.802 & 2.084 & & 252 & 2.4 & & 4.549 & 2.395 & & -2.700 & 1.570 & \\
\hline & G.969 & M & 4.607 & 2.629 & 0.3104 & -2.980 & 2.134 & 0.5087 & -0.811 & 2.5205 & 0.9883 & 3.755 & 2.453 & 0.4288 & 7.134 & 1.604 & 0.0004 \\
\hline & .116 & (9-135. & -2.965 & 2.629 & 0.6745 & 4.822 & 2.134 & 0.1245 & -4.063 & 2.5205 & 0.3833 & -0.794 & 2.453 & 0.9881 & 9.833 & 1.604 & $<0.0001$ \\
\hline \multirow[t]{4}{*}{ Golden } & G.935 & G.969 & 12.035 & 3.586 & 0.0089 & -0.450 & 0.968 & 0.9663 & -4.911 & 1.7207 & 0.0327 & 5.361 & 2.106 & 0.0677 & & & \\
\hline & G.935 & M.116 & -3.782 & 3.672 & 0.733 & 2.291 & 0.991 & 0.1123 & 1.017 & 1.7625 & 0.9385 & -3.313 & 2.157 & 0.4259 & & & \\
\hline & 935 & & 2.787 & 3.586 & & 52 & 0.968 & & -5.232 & & & 4.679 & 2.106 & & & & \\
\hline & & & -15.818 & 3.672 & & & 0.991 & & & & & -8.674 & 2.157 & & & & \\
\hline
\end{tabular}

$\mathrm{AFW}=$ average fruit weight per tree; $\%<70 \mathrm{~mm}=$ percent of fruit under $70 \mathrm{~mm}$ in diameter; $\% 70-80 \mathrm{~mm}=$ percent of fruit between $70-80 \mathrm{~mm}$ in diameter; $\%>80 \mathrm{~mm}=$ percent of fruit greater than $70 \mathrm{~mm}$ in diameter.

Fruit red color is an important parameter when sorting 'Fuji' and 'Gala' apples where a higher percentage of red color means better returns for the grower (Tables 3 and 4). Both the 'Fuji' and the 'Gala' experiments showed significant rootstock effects on percent red color. Fruit from 'Fuji' on 'M.9-T337' had the highest red color compared with the other rootstocks. Conversely, Gala on 'M.9-T337' had the lowest percentage of fruit red color. Fruit red color can be affected by many variables, including crop load, water, nutrition, light exposure, maturity, temperature, distribution in the tree canopy (Fallahi et al., 2011; Musacchi and Serra, 2018; Neilsen and Neilsen, 2006; Reig et al., 2019a; Serra et al., 2016), which can all be affected in part by rootstock genotype. This is evidenced by the relationships highlighted in Fig. 4, which shows one of the most impactful effects on fruit color is average fruit number per tree (AFN), but that relationship is in fact influenced by rootstock genotype.

Gross income. Rootstocks in the context of scion cultivar and training systems can have a significant effect on gross farm gate returns (Lordan et al., 2019a, 2019b; Robinson, 2008; Robinson et al., 2007). When yield and fruit quality parameters were considered and combined with representative returns for local packing houses (in Euros; data not shown), we found that rootstocks

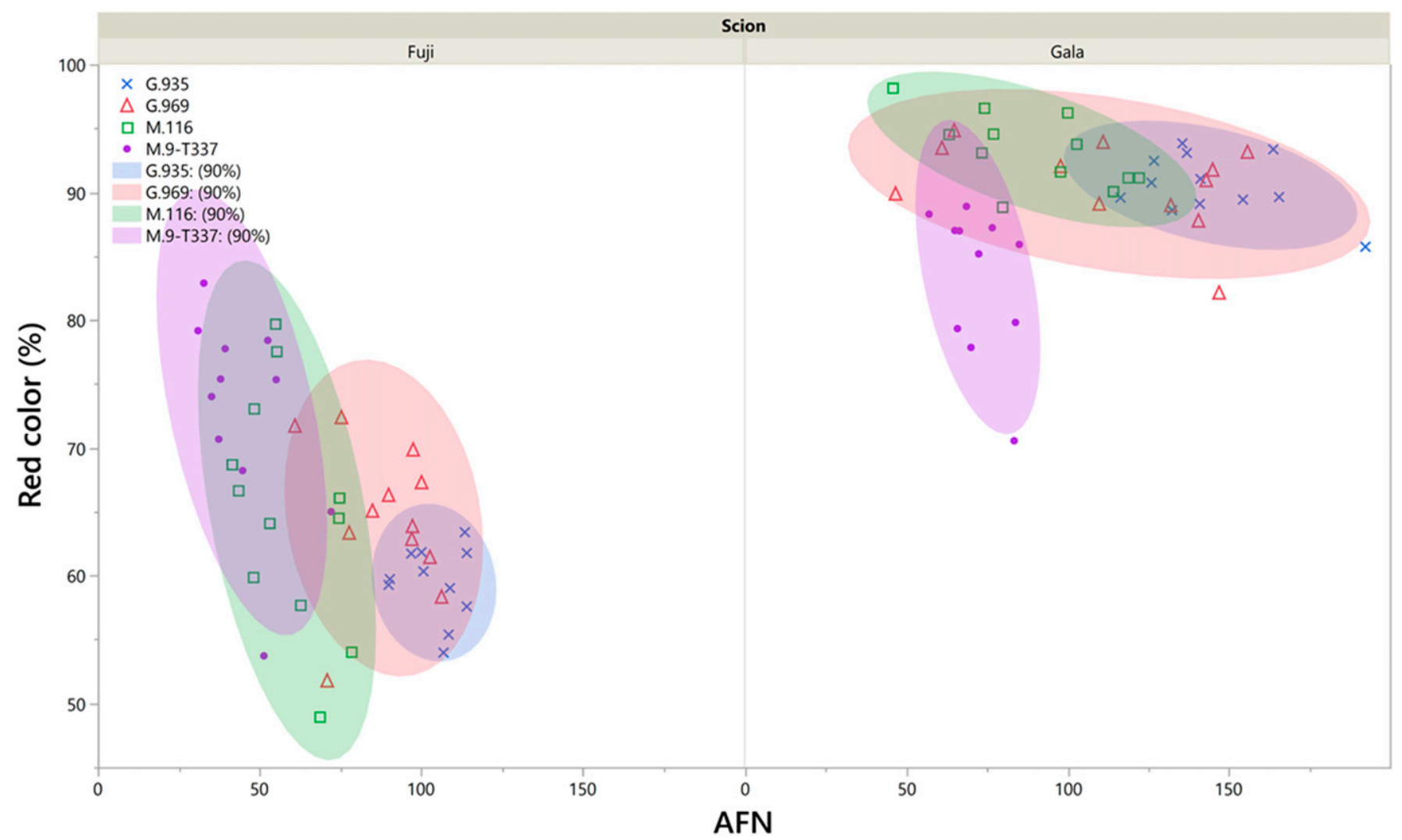

Fig. 4. Relationships between percent red color and average fruit number (AFN) by experiment ('Fuji' and 'Gala') and rootstock. Shaded ellipse represents $95 \%$ confidence interval. Planting located at the Edmund Mach Foundation experimental station of Maso delle Part, Trentino, Italy. 


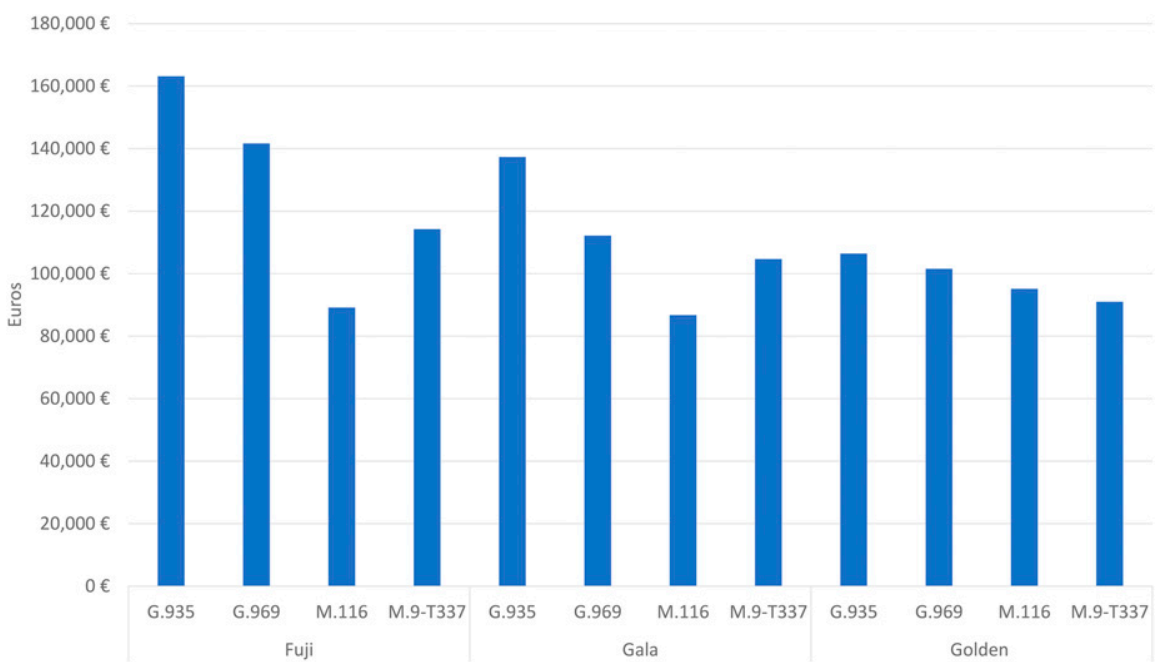

Fig. 5. Cumulative gross income per hectare (2015-19) based on representative packing house returns adjusted for fruit size and color attributes. Planting located at the Edmund Mach Foundation experimental station of Maso delle Part, Trentino, Italy.

had a dramatic effect on the cumulative gross crop value per hectare (Fig. 5). 'G.935' seemed to consistently provide the highest cumulative crop value. Although this represents gross farm gate values, we should note that the management expenses within the different experiments were the same, with perhaps small differences in the cost of the trees (Biaxis 3175 trees/ha - Euros: 23.813/ha; triaxis was 2116 trees/ha - Euros: 21.160/ha). Tree management costs were similar for all trees as the same number of leaders/ha (6350) was the same however higher yields with 'G.935' would result in slightly higher harvest costs.

\section{Conclusions}

This study shows that even semidwarf rootstocks could be suitable not only for weak scions but for high-density planting systems with multileader systems of normal vigor varieties. Tree training, tree density, and pruning have a big impact on tree size, as found by Reig et al. (2020).

All the semidwarf genotypes produced a higher yield compared with the common 'M.9-T337', the industry standard for that region. Only Gala on 'M.116' had similar performance to 'M.9-T337'. Increasing tree density or leader (axes) density can increase yield per hectare (Lordan et al., 2018). In this trial, the triaxis on ' $\mathrm{G} .935$ ' performed better than the higher tree density 'M.9-T337' in all the cultivars, without affecting fruit quality in terms of fruit size. Given the canopy volume data (Fig. 2) further adjustments in tree/ leader density could be made for each rootstock given the tree size potential differences between triaxis 'G.935', 'G.969', and 'M.116'. Perhaps 'G.935' could be used for biaxis training systems, thereby increasing tree density slightly and consequently increasing yield per hectare.

'G.935' showed itself to be a productive rootstock with all the tested cultivars and had a similar yield efficiency ('Gala' and 'Golden
Delicious') or higher yield efficiency ('Fuji') than 'M.9-T337'. According to Robinson et al. (2011b), generally yield efficiency of a rootstock is inversely related to its vigor, but in this experiment, contrary results were found. 'G.969' performed similarly to 'M.9T337' only with vigorous cultivars such as 'Fuji'.

Both the Geneva ${ }^{\circledR}$ genotypes are particularly interesting because they are tolerant to biotic and abiotic stressors, such as fire blight, Phytophthora root rot and replant disease. In addition, 'G.969' is tolerant to woolly aphids, which is one of the main issues in Fuji cultivar and in organic farms in the Trentino region. 'M.116', tolerant to Phytophthora root rot only, was slightly more vigorous and needed time to reach a sustainable production despite a good performance particularly with Golden Delicious cultivar. Finally, it is clear that rootstock choice can affect return on the investment in an apple orchard, and apple growers should consider novel opportunities when planning to establish or replant an orchard because that choice has the potential to make the business profitable.

\section{Literature Cited}

Adams, S., J. Lordan, G. Fazio, B. Bugbee, P Francescatto, T.L. Robinson, and B. Black. 2018. Effect of scion and graft type on transpiration, hydraulic resistance and xylem hormone profile of apples grafted on Geneva41 and M.9NICTM29 rootstocks. Scientia Hort. 227:213222, doi: 10.1016/j.scienta.2017.09.052.

Autio, W., T. Robinson, B. Black, S. Blatt, D. Cochran, W. Cowgill, C. Hampson, E. Hoover, G. Lang, D. Miller, I. Minas, R.P. Quezada, and M. Stasiak. 2017a. Budagovsky, Geneva, Pillnitz, and Malling apple rootstocks affect 'Honeycrisp' performance over the first five years of the 2010 NC-140 'Honeycrisp' Apple Rootstock Trial. J. Amer. Pomol. Soc. 71:149-166. Autio, W., T. Robinson, B. Black, R. Crassweller, E. Fallahi, M. Parker, R.P. Quezada, and D. Wolfe. 2017b. Budagovsky, Geneva, Pillnitz, and Malling apple rootstocks affect 'Fuji' per- formance over the first five years of the 2010 NC-140 'Fuji' Apple Rootstock Trial. J. Amer. Pomol. Soc. 71:167-182.

Autio, W.R., T.L. Robinson, B.H. Barritt, J.A Cline, R.M. Crassweller, C.G. Embree, D.C. Ferree, M.E. Garcia, G.M. Greene, E.E. Hoover, R.S. Johnson, K. Kosola, J. Masabni, M.L. Parker, R.L. Perry, G.L. Reighard, S.D. Seeley, and M. Warmund. 2005. Performance of 'Fuji' and 'Mcintosh' apple trees after 5 years as affected by several dwarf rootstocks in the 1999 NC-140 Apple Rootstock Trial. J. Amer. Pomol. Soc. 59:202-214.

Autio, W.R., T.L. Robinson, B. Black, T. Bradshaw, J.A. Cline, R.M. Crassweller, C.G. Embree, E.E. Hoover, S.A. Hoying, K.A. Iungerman, R.S. Johnson, G. Lang, M.L. Parker, R.L. Perry, G.L. Reighard, J.R. Schupp, M. Stasiak, M. Warmund, and D. Wolfe. 2011. Performance of 'Fuji' and 'McIntosh' apple trees after 10 years as affected by several dwarf rootstocks in the $1999 \mathrm{NC}-140$ apple rootstock trial. J. Amer. Pomol. Soc. 65:2-20.

Chavez-Gonzalez, C.H., R.A. Parra-Quezada, M.R. Ramirez-Legarreta, and J.L. JacoboCuellar. 2011. Early performance of 'Buckeye Gala' grafted on 13 apple rootstocks in Mexico. Acta Hort. 903:301-304.

Chun, I.J., E. Fallahi, R.R. Tripepi, W.M. Colt, and B. Shafii. 2002. Vegetative growth and mixed-bud development of 'Fuji' apple trees as influenced by rootstocks and microsprinkler fertigation. J. Amer. Pomol. Soc. 56:14-22.

Dallabetta, N., M. Giordan, A. Guerra, and J. Pasqualini. 2018. The performance of Geneva apple rootstocks in the province of Trento. Acta Hort. 1228:153-159.

DeMarree, A., T.L. Robinson, and S.A. Hoying. 2003. Economics and the orchard system decision. Compact Fruit Tree 36:42-49.

Dorigoni, A., P. Lezzer, N. Dallabetta, S. Serra, and S. Musacchi. 2011. Bi-axis: An alternative to slender spindle for apple orchards. Acta Hort. 903:581-588.

Fallahi, E., B. Fallahi, B. Shafii, and J.R. McFerson. 2011. The impact of rootstock and irrigation on water use, tree growth, nutrition, yield, and fruit quality of 'Pacific Gala' apple. Acta Hort. 903:915-921.

Fallahi, E., M.J. Kiester, B. Fallahi, and S. Mahdavi. 2018. Rootstock, Canopy Architecture, Bark Girdling, and Scoring Influence on Growth, Productivity, and Fruit Quality at Harvest in 'Aztec Fuji' Apple. HortScience 53:1629-1633.

Fazio, G., L. Cheng, J. Lordan, P. Francescatto, M.A. Grusak, and T.L. Robinson. 2018. Breeding apple rootstocks for modulation of mineral nutrients in scions. Acta Hort. 1217:29-37.

Fazio, G., J. Lordan, M.A. Grusak, P. Francescatto, and T.L. Robinson. 2020. I. Mineral nutrient profiles and relationships of 'Honeycrisp' grown on a genetically diverse set of rootstocks under Western New York climatic conditions. Scientia Hort. 266:108477, doi: 10.1016/j.scienta.2019.05.004.

Fazio, G. and T. Robinson. 2008a. Modification of nursery tree architecture by apple rootstocks. HortScience 43:1271.

Fazio, G. and T.L. Robinson. 2008b. Modification of nursery tree architecture with apple rootstocks: a breeding perspective. New York Fruit Quarterly 16:13-16.

Fazio, G., Y. Wan, D. Kviklys, L. Romero, R.R. Adams, D. Strickland, and T.L. Robinson. 2014. Dw2, a New Dwarfing Locus in Apple Rootstocks and Its Relationship to Induction of Early Bearing in Apple Scions. J. Amer. Soc. Hort. Sci. 139:87-98. 
Gallardo, R.K. and M.P. Brady. 2015. Adoption of labor-enhancing technologies by specialty crop producers: The case of the Washington apple industry. Agr. Financ. Rev. 75:514-532.

Green, S.R., D.H. Greer, J.N. Wunsche, H. Caspari, and J.W. Palmer. 2001. Measurements of light interception and utilization in an apple orchard. Acta Hort. 557:369-376.

Lordan, J., G. Fazio, P. Francescatto, and T. Robinson. 2017. Effects of apple (Malus $\times$ domestica) rootstocks on scion performance and hormone concentration. Scientia Hort. 225:96-105, doi: 10.1016/j.scienta.2017.06.050.

Lordan, J., G. Fazio, P. Francescatto, and T.L. Robinson. 2019a. II. Horticultural performance of 'Honeycrisp' grown on a genetically diverse set of rootstocks under Western New York climatic conditions. Scientia Hort. 257:108686, doi: 10.1016/j.scienta.2019.108686.

Lordan, J., P. Francescatto, L.I. Dominguez, and T.L. Robinson. 2018. Long-term effects of tree density and tree shape on apple orchard performance, a 20 year study-Part 1, agronomic analysis. Scientia Hort. 238:303-317, doi: 10.1016/j.scienta.2018.04.033.

Lordan, J., M. Gomez, P. Francescatto, and T.L. Robinson. 2019b. Long-term effects of tree density and tree shape on apple orchard performance, a 20 year study - part 2, economic analysis. Scientia Hort. 244:435-444, doi: 10.1016/j.scienta.2018.03.031.

Marini, R.P., B. Black, R.M. Crassweller, P.A. Domoto, C. Hampson, S. Johnson, K. Kosola, S. McArtney, J. Masabni, R. Moran, R.P. Quezada, T. Robinson, and C.R. Rom. 2009. Performance of 'Golden Delicious' apple on 23 rootstocks at 12 locations: A five-year summary of the 2003 nc-140 dwarf rootstock trial. J. Amer. Pomol. Soc. 63:115-127.

Marini, R.P., B. Black, R.M. Crassweller, P.A. Domoto, C. Hampson, R. Moran, T. Robinson, M. Stasiak, and D. Wolfe. 2014. Performance of 'Golden Delicious' apple on 23 rootstocks at eight locations: A ten-year summary of the 2003 NC-140 dwarf rootstock trial. J. Amer. Pomol. Soc. 68:54-68.

Mazzola, M. 1998. Elucidation of the microbial complex having a causal role in the development of apple replant disease in Washington. Phytopathology 88:930-938.

Musacchi, S. and S. Serra. 2018. Apple fruit quality: Overview on pre-harvest factors. Scientia Hort. 234:409-430, doi: 10.1016/j.scienta.2017.12.057.

Neilsen, G.H. and D. Neilsen. 2006. The effect of K-fertilization on apple fruit Ca concentration and quality. Acta Hort. 721:177-183.

Palmer, J.W. 2011. Changing concepts of efficiency in orchard systems. Acta Hort. 903:41-49.

Reig, G., J. Lordan, G. Fazio, M.A. Grusak, S. Hoying, L.L. Cheng, P. Francescatto, and T. Robinson. 2018. Horticultural performance and elemental nutrient concentrations on 'Fuji' grafted on apple rootstocks under New York State climatic conditions. Scientia Hort. 227:22-37, doi: 10.1016/j.scienta.2018.11.029.

Reig, G., J. Lordan, S. Hoying, M. Fargione, D.J. Donahue, P. Francescatto, D. Acimovic, G. Fazio, and T. Robinson. 2020. Long-term performance of 'Delicious' apple trees grafted on Geneva ${ }^{\circledR}$ rootstocks and trained to four highdensity systems under New York State climatic conditions. HortScience 55:1538-1550, doi: 10.21273/HORTSCI14904-20.

Reig, G., J. Lordan, M.M. Sazo, S. Hoying, M. Fargione, G. Reginato, D.J. Donahue, P. Francescatto, G. Fazio, and T. Robinson. 2019a. Long-term performance of 'Gala', Fuji' and 'Honeycrisp' apple trees grafted on Geneva (R) rootstocks and trained to four production systems under New York State climatic conditions. Scientia Hort. 244:277-293, doi: 10.1016/j.scienta.2018.09.025.

Reig, G., J. Lordan, M.M. Sazo, S.A. Hoying, M.J. Fargione, G.H. Reginato, D.J. Donahue, P. Francescatto, G. Fazio, and T.L. Robinson. $2019 \mathrm{~b}$. Effect of tree type and rootstock on the long-term performance of 'Gala', 'Fuji' and 'Honeycrisp' apple trees trained to Tall Spindle under New York State climatic conditions. Scientia Hort. 246:506-517, doi: 10.1016/j.scienta.2018.11.029.

Robinson, T. 2008. The evolution towards more competitive apple orchard systems in the USA. Acta Hort. 772:491-500.

Robinson, T. 2011. Advances in apple culture worldwide. Rev. Bras. Frutic. 33:37-47.

Robinson, T.L., B.H. Barritt, and F. Kappel. 1997. Interaction of tree form and rootstock on light interception, yield and efficiency of 'Empire', 'Delicious' and 'Jonagold' apple trees trained to different systems. Acta Hort. 451:427-436.

Robinson, T.L., A.M. DeMarree, and S.A. Hoying. 2007. An economic comparison of five high density apple planting systems. Acta Hort. 732:481-489.

Robinson, T.L., L.I. Dominguez, and F. Acosta. 2016. Pruning strategy affects fruit size, yield and biennial bearing of 'Gala' and 'Honeycrisp' apples. Acta Hort. 1130:257-264.

Robinson, T.L., G. Fazio, and H.S. Aldwinckle. 2014. Characteristics and performance of four new apple rootstocks from the Cornell-USDA apple rootstock breeding program. Acta Hort. 1058:651-656.

Robinson, T.L., G. Fazio, S. Hoying, M. Miranda, and K. Iurgerman. 2011a. Geneva ${ }^{\circledR}$ rootstocks for weak growing scion cultivars like "Honeycrisp". New York Fruit Quarterly 19:10-16.

Robinson, T.L., S.A. Hoying, and G. Fazio. 2011 b. Performance of Geneva rootstocks in on-farm trials in New York State. Acta Hort. 903:249255.

Robinson, T.L., A.N. Lakso, and Z.B. Ren. 1991. Modifying apple tree canopies for improved production efficiency. HortScience 26:10051012.

Rufato, A.D., T.L. Robinson, and L. Rufato. 2017. Precision thinning of 'Royal Gala' apple trees using the fruit growth model. Acta Hort. 1177:399-404.

Russo, N.L., T.L. Robinson, G. Fazio, and H.S. Aldwinckle. 2007. Field evaluation of 64 apple rootstocks for orchard performance and fire blight resistance. HortScience 42:1517-1525.

Sansavini, S., D. Bassi, and L. Giunchi. 1981. Tree efficiency and fruit quality in high-density apple orchards. Acta Hort. 114:114-136.

Serra, S., R. Leisso, L. Giordani, L. Kalcsits, and S. Musacchi. 2016. Crop load influences fruit quality, nutritional balance, and return bloom in 'Honeycrisp' apple. HortScience 51:236244.

Spath, M., H. Insam, U. Peintner, M. Kelderer, R. Kuhnert, and I.H. Franke-Whittle. 2015. Linking soil biotic and abiotic factors to apple replant disease: A greenhouse approach. J. Phytopathol. 163:287-299.

Stutte, G.W., T.A. Baugher, S.P. Walter, D.W. Leach, D.M. Glenn, and T.J. Tworkoski. 1994. Rootstock and training system affect dry-matter and carbohydrate distribution in 'Golden Delicious' apple trees. J. Amer. Soc. Hort. Sci. 119:492-497.

Tustin, D.S. and B.M. van Hooijdonk. 2016. Can light interception of intensive apple and pear orchard systems be increased with new approaches to tree design? Acta Hort. 1130:139144.

van Hooijdonk, B., D. Woolley, I. Warrington, and S. Tustin. 2011. Rootstocks modify scion architecture, endogenous hormones, and root growth of newly grafted 'Royal Gala' apple trees. J. Amer. Soc. Hort. Sci. 136:93-102.

van Hooijdonk, B.M., D.S. Tustin, M.J. Oliver, and G.A. Dayatilake. 2016. Leaf area development and dry matter production of newly grafted monoaxis and biaxis apple trees. Acta Hort 1130:335-340.

Wallis, A., J.M. Harshman, B. Butler, D. Price, G. Fazio, and C. Walsh. 2017. Performance of Geneva (R) apple rootstock selections with 'Brookfield Gala' and 'Cripps Pink' in a tall spindle system. J. Amer. Pomol. Soc. 71:137148.

Wunsche, J.N. and I.B. Ferguson. 2005. Crop load interactions in apple. Hort. Rev. 31:231-290.

Wunsche, J.N. and A.N. Lakso. 2000. The relationship between leaf area and light interception by spur and extension shoot leaves and apple orchard productivity. HortScience 35:1202-1206.

Yildirim, F., E. Vural, Y. Ucar, and A.N. Yildirim. 2016. Interaction of crop load and irrigation on yield, fruit size, color and stem-end splitting ratio of apple c.v 'Gala, Galaxy'. ErwerbsObstbau 58:103-111. 


Yr Fuji Gala Golden

2015 The chemical thinning was done by a double ATS The chemical thinning was done by a double ATS The chemical thinning was done by a double ATS
(Ammonium thiosulfate) treatment (Ammonium thiosulfate) treatment (Ammonium thiosulfate) treatment

1 st treatment - Ger-ATS LG® (1.Gobbi) 15 LHa-1 - When the flowers on the wood of 1st treatment - Ger-ATS LG® (1.Gobbi) 15 L-Ha-1 1st treatment - Ger-ATS LG® (1.Gobbi) 15 L-Ha- When the flowers on the wood of several years are several years are in full bloom/starting central in full bloom/starting central flower petal fall flower petal fall

in full bloom/starting central flower petal fall 1 - When the flowers on the wood of several years are in full bloom/starting central flower

2nd treatment - Ger-ATS LG (1.Gobbi) $15 \mathrm{~L}-\mathrm{Ha}-1$ - When the flowers on young 1 year old wood are in 2nd treatment-Ger-ATS LGß (1.Gobbi) $15 \mathrm{~L}-\mathrm{Ha}-1$ - When the flowers on young 1 year old wood are full bloom/starting central flower petal fall

- When the flowers on young 1 year old wood are in in full bloom/starting central flower petal fall Trees were manually thinned later if needed. Trees were manually thinned later if needed.

2016 1st treatment - Ammonium Thiosulfate (ATS) Ger-ATS LG® 1.gobbi [Total nitrogen (N) $12 \%$, Ammoniacal nitrogen $(\mathrm{N}) 12 \%$, Sulphuric anhydride (SO3) soluble in water $65 \%$ ] - 15 L-Ha-1. When the flowers on the wood of several years are in full bloom/starting central flower petal fall.

2nd treatment - Ammonium Thiosulfate (ATS) Ger-ATS LG® 1.gobbi [Total nitrogen (N) 12 $\%$, Ammoniacal nitrogen (N) 12\%, Sulphuric anhydride (SO3) soluble in water $65 \%$ ] - $15 \mathrm{~L}$ Ha-1. When the flowers on young 1-year old wood are in full bloom/starting central flower petal fall.

Trees were manually thinned later if needed.

1st treatment - Ammonium Thiosulfate (ATS) Ger-ATS LG ${ }^{\circledR}$ l.gobbi [Total nitrogen (N) $12 \%$, Ammoniacal nitrogen (N) 12\%, Sulphuric anhydride (SO3) soluble in water $65 \%$ ] - 15 L-Ha-1. When the flowers on the wood of several years are in full bloom/starting central flower petal fall.

2nd treatment - Ammonium Thiosulfate (ATS) Ger-ATS LG® 1.gobbi [Total nitrogen (N) $12 \%$, Ammoniacal nitrogen (N) 12\%, Sulphuric anhydride (SO3) soluble in water $65 \%$ ] - 15 L-Ha-1. When the flowers on young 1-year old wood are in full bloom/starting central flower petal fall.

3rd treatment - 6-Benziladenina - Brancher Dirado 3rd treatment - 6-Benziladenina - Brancher Dirado Orius / Fine Agrochemicals $(9.4 \%$ Benzyladenine) - 100 ppm or 1,5 L-Ha-1 + Naphthalene acetic acid (NAA) - Dirager ${ }^{\circledR}$ 1.gobbi (3.3\% NAA) - 0.150 L-Ha-1. When the central fruit diameter was $10 \mathrm{~mm}$.

In years 2018 and 2019 in the 1 st treatment was added Ethephon - Ethrel® Bayer (39.6\% Ethepon) - 0.300 L-Ha-1.

Trees were manually thinned later if needed.

2017 1st treatment - Ammonium Thiosulfate (ATS) Ger-ATS LG ${ }^{\circledR}$ 1.gobbi [Total nitrogen (N) 12 $\%$, Ammoniacal nitrogen (N) $12 \%$, Sulphuric anhydride (SO3) soluble in water $65 \%$ ] - $15 \mathrm{~L}$ Ha-1. When the flowers on the wood of several years are in full bloom/starting central flower petal fall.

2nd treatment - Ammonium Thiosulfate (ATS) Ger-ATS LG® 1.gobbi [Total nitrogen (N) 12 $\%$, Ammoniacal nitrogen (N) 12\%, Sulphuric anhydride (SO3) soluble in water $65 \%$ ] - $15 \mathrm{~L}$ Ha-1. When the flowers on young 1-year old wood are in full bloom/starting central flower petal fall.

Orius / Fine Agrochemicals $(9.4 \%$

Benzyladenine) - 100 ppm or 1,5 L-Ha-1 + Naphthalene acetic acid (NAA) - Dirager ${ }^{\circledR}$ 1.gobbi (3.3\% NAA) - 0.150 L-Ha-1. When the central fruit diameter was $10 \mathrm{~mm}$.

Trees were manually thinned later if needed.

1st treatment - Ammonium Thiosulfate (ATS) Ger-ATS LG ${ }^{\circledR}$ 1.gobbi [Total nitrogen (N) $12 \%$, Ammoniacal nitrogen (N) 12\%, Sulphuric anhydride (SO3) soluble in water $65 \%$ ] - $15 \mathrm{~L}$ Ha-1. When the flowers on the wood of several years are in full bloom/starting central flower petal fall.

2nd treatment - Ammonium Thiosulfate (ATS) Ger-ATS LG ${ }^{\circledR}$ 1.gobbi [Total nitrogen (N) $12 \%$, Ammoniacal nitrogen (N) $12 \%$, Sulphuric anhydride (SO3) soluble in water $65 \%$ ] - $15 \mathrm{~L}$ Ha-1. When the flowers on young 1-year old wood are in full bloom/starting central flower petal fall.

3rd treatment - 6-Benziladenina - Brancher Dirado 3rd treatment - 6-Benziladenina - Brancher Dirado Orius / Fine Agrochemicals ( $9.4 \%$ Benzyladenine) - 100 ppm or 1,5 L-Ha-1 + Naphthalene acetic acid (NAA) - Dirager ${ }^{\circledR}$ 1.gobbi (3.3\% NAA) - 0.150 L-Ha-1. When the central fruit diameter was $10 \mathrm{~mm}$.

In years 2018 and 2019 in the 1 st treatment was added Ethephon - Ethrel® Bayer (39.6\%

Ethepon) - 0.300 L-Ha-1.

Trees were manually thinned later if needed.
Orius / Fine Agrochemicals $(9.4 \%$

Benzyladenine) - 100 ppm or 1,5 L-Ha-1 + Naphthalene acetic acid (NAA) - Dirager ${ }^{\circledR}$ 1.gobbi (3.3\% NAA) - 0.150 L-Ha-1. When the central fruit diameter was $10 \mathrm{~mm}$.

Trees were manually thinned later if needed. full bloom/starting central flower petal fall

Trees were manually thinned later if needed.

1st treatment - Naphthalene acetamide (NAD) Amid Thin W Sumitomo Agrochemical Italia (8.4\% NAD) - $1.5 \mathrm{~kg}-\mathrm{Ha}-1$. Full Bloom when the flowers on the wood of several years are in full bloom/starting central flower petal fall.

2nd treatment - 6-Benziladenina - Brancher Dirado Orius / Fine Agrochemicals (9.4\% Benzyladenine) - 100 ppm or 1,5 L-Ha-1 + Naphthalene acetic acid (NAA) - Dirager ${ }^{\circledR}$ 1.gobbi (3.3\% NAA) - 0.150 L-Ha- 1 . When the central fruit diameter was $10 \mathrm{~mm}$.

Trees were manually thinned later if needed. 1st treatment - Naphthalene acetamide (NAD) Amid Thin W Sumitomo Agrochemical Italia (8.4\% NAD) - 1.5 kg-Ha-1. Full Bloom when the flowers on the wood of several years are in full bloom/starting central flower petal fall.

2nd treatment - 6-Benziladenina - Brancher Dirado Orius / Fine Agrochemicals $(9.4 \%$ Benzyladenine) - 100 ppm or 1,5 L-Ha-1 + Naphthalene acetic acid (NAA) - Dirager ${ }^{\circledR}$ 1.gobbi (3.3\% NAA) - 0.150 L-Ha-1. When the central fruit diameter was $10 \mathrm{~mm}$.

Trees were manually thinned later if needed. 
Supplemental Table 1. (Continued) Thinning strategies by variety and year.

\begin{tabular}{|c|c|c|c|}
\hline Yr & Fuji & Gala & Golden \\
\hline
\end{tabular}
$65 \%$ ] - 15 L-Ha-1. When the flowers on young Trees were manually thinned later if needed. 1 -year old wood are in full bloom/starting central flower petal fall.

3rd treatment - 6-Benziladenina - Brancher Dirado Orius / Fine Agrochemicals $(9.4 \%$

Benzyladenine) - 100 ppm or 1,5 L-Ha-1 + Naphthalene acetic acid (NAA) - Dirager ${ }^{\circledR}$ 1.gobbi (3.3\% NAA) - 0.150 L-Ha-1. When the central fruit diameter was $10 \mathrm{~mm}$.

In the 1st treatment was added Ethephon - Ethrel ${ }^{\circledR}$ Bayer (39.6\% Ethepon) - 0.300 L-Ha-1.

Trees were manually thinned later if needed.

2019 1st treatment - Ammonium Thiosulfate (ATS) Ger-ATS LG® 1.gobbi [Total nitrogen (N) 12 $\%$, Ammoniacal nitrogen (N) $12 \%$, Sulphuric anhydride (SO3) soluble in water $65 \%$ - $15 \mathrm{~L}$ Ha-1. When the flowers on the wood of several years are in full bloom/starting central flower petal fall.

2nd treatment - Ammonium Thiosulfate (ATS) Ger-ATS LG® 1.gobbi [Total nitrogen (N) 12 $\%$, Ammoniacal nitrogen (N) $12 \%$, Sulphuric anhydride (SO3) soluble in water $65 \%$ ] - $15 \mathrm{~L}$ Ha-1. When the flowers on young 1-year old wood are in full bloom/starting central flower

1st treatment - Naphthalene acetamide (NAD) Amid Thin W Sumitomo Agrochemical Italia (8.4\% NAD) - $1.2 \mathrm{~kg}-\mathrm{Ha}-1$. Full Bloom when the flowers on the wood of several years are in full bloom/starting central flower petal fall.

2nd treatment - 6-Benziladenina - Brancher Dirado Orius / Fine Agrochemicals (9.4\% Benzyladenine) - 100 ppm or 1,5 L-Ha-1 + Naphthalene acetic acid (NAA) - Dirager ${ }^{\circledR}$ 1.gobbi (3.3\% NAA) - 0.150 L-Ha-1. When the central fruit diameter was $10 \mathrm{~mm}$.

Trees were manually thinned later if needed.
Trees were manually thinned later if needed. petal fall.

3rd treatment - 6-Benziladenina - Brancher Dirado Orius / Fine Agrochemicals (9.4\% Benzyladenine) - 100 ppm or 1,5 L-Ha-1 + Naphthalene acetic acid (NAA) - Dirager ${ }^{\circledR}$ 1.gobbi (3.3\% NAA) - 0.150 L-Ha-1. When the central fruit diameter was $10 \mathrm{~mm}$.In the 1st treatment was added Ethephon - Ethrel ${ }^{\circledR}$ Bayer (39.6\% Ethepon) - 0.300 L-Ha-1.

Trees were manually thinned later if needed.

1st treatment - Naphthalene acetamide (NAD) Amid Thin W Sumitomo Agrochemical Italia (8.4\% NAD) - $1.5 \mathrm{~kg}-\mathrm{Ha}-1$. Full Bloom when the flowers on the wood of several years are in full bloom/starting central flower petal fall. 2nd treatment - 6-Benziladenina - Brancher Dirado Orius / Fine Agrochemicals $(9.4 \%$ Benzyladenine) - 100 ppm or 1,5 L-Ha-1 + Naphthalene acetic acid (NAA) - Dirager ${ }^{\circledR}$ 1.gobbi (3.3\% NAA) - 0.150 L-Ha- 1 . When the central fruit diameter was $10 \mathrm{~mm}$.

Trees were manually thinned later if needed. 